\title{
Chapter 4 \\ Conventional and Molecular Breeding Approaches for Biofortification of Pearl Millet
}

\author{
M. Govindaraj, O. P. Yadav, R. K. Srivastava, and S. K. Gupta
}

\subsection{Introduction}

Pearl millet [Pennisetum glaucum (L.) R. Br.] is an essential diet of more than 90 million people in the semi-arid tropics of the world where droughts and low fertility of soils cause frequent failures of other crops. It is an important nutri-rich grain cereal in the drier regions of the world grown on 26 mha by millions of farmers (IFAD 1999; Yadav and Rai 2013). This makes pearl millet the sixth most important crop in the world and fourth most important food crop of the India, next to rice, wheat, and maize with annual cultivation over an area of $\sim 8$ mha. Pearl millet is also primary food crop in sub-Saharan Africa and is grown on 15 mha (Yadav and Rai 2013). The significant increase in productivity of pearl millet in India is attributed to development and adoption of hybrids of early to medium duration maturity. More than 120 diverse hybrids/varieties have been released till date for various production environments. The heterosis breeding and improved crop management technologies increased productivity substantially achieving higher increased production of $9.80 \mathrm{mt}$ in 2016-2017 from $2.60 \mathrm{mt}$ in 1950-1951 in spite of declined of area under the crop by 20-30\% over last two decades (Yadav et al. 2012).

Over 50\% pearl millet grain production in Asia is utilized for food purpose and the $20 \%$ is used for feed, while $100 \%$ grain is used as food in west and central Africa. The per capita consumption of pearl millet in India is highest among rural population in the western Rajasthan and Gujarat, contributing to more than $50 \%$ of cereal consumption in these regions (Parthasarathy Rao et al. 2006). Pearl millet

M. Govindaraj · R. K. Srivastava $\cdot$ S. K. Gupta

International Crops Research Institute for the Semi-Arid Tropics (ICRISAT),

Patancheru, Telanagana, India

e-mail: m.govindaraj@cgiar.org; r.k.srivastava@cgiar.org; s.gupta@cgiar.org

O. P. Yadav $(\bowtie)$

Central Arid Zone Research Institute, Jodhpur, Rajasthan, India

e-mail: director.cazri@icar.gov.in 
grain is also consumed in other parts of Maharashtra and Haryana (Basavaraj et al. 2010). Likewise, the domestic consumption of pearl millet is rising steadily in Africa (Ajetomobi 2008).

Pearl millet is a rich source of energy (361 Kcal $100 \mathrm{~g}^{-1}$ ) comparable with other cereals such as wheat $\left(346 \mathrm{Kcal} 100 \mathrm{~g}^{-1}\right)$, rice $\left(345 \mathrm{Kcal} 100 \mathrm{~g}^{-1}\right)$, maize

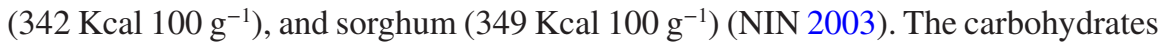

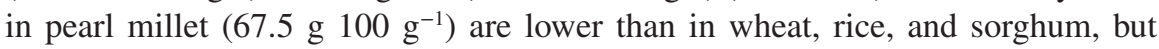
higher than in maize, while germ portion of pearl millet is larger than sorghum (NIN 2003). These differences explain pearl millet having lower starch and higher protein

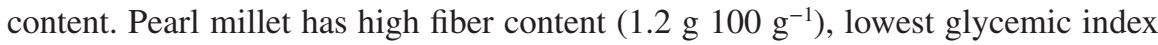
(55) among cereals (Mani et al. 1993), and has relatively higher methionine and phytochemicals and micronutrients (Mal et al. 2010; Singh et al. 2012). Pearl millet is also rich in calcium, potassium, magnesium, iron, zinc, manganese, riboflavin, thiamine, niacin, lysine, and tryptophan.

Shrinking of food basket to a few fine cereals like wheat and rice largely due to subsidized government price and distribution policies for these two cereals has contributed to inadequate intake of essential micronutrients such as iron $(\mathrm{Fe})$ and Zinc (Zn). Fe deficiency affects more than $30 \%$ of the population globally, and highest prevalence of anemia is reported among preschool-age children (47\%) and pregnant women $(42 \%)$ (WHO 2008). An estimated $20 \%$ of the global population is at risk of inadequate $\mathrm{Zn}$ intake (Wessells and Brown 2012). Thus, deficiency of Fe and $\mathrm{Zn}$ is most prevalent worldwide. Although government-supported program in India showed marginal reduction in malnutrition over the decades, the progress is very slow as National Family Health Survey revealed unacceptably high prevalence of anemia (>55\%), under-weight (35\%), and stunting (38\%) among children under 5 years (NFHS 2016). The intake of Fe and $\mathrm{Zn}$ appears to be below the recommended dietary allowance for an average Indian adult particularly in the low-income rural households including the pearl millet-consuming regions (ICMR 2002; Parthasarathy Rao et al. 2006). Interestingly, pearl millet serves as a significant source of dietary energy and contributes to $19-63 \%$ of the Fe and $16-56 \%$ of the $\mathrm{Zn}$ intake from all food sources to a vast population in parts of the major pearl millet growing states of India (Parthasarathy Rao et al. 2006).

Addressing the micronutrient malnutrition through supplementations and food fortification has been initiated but has not been found as a sustainable approach in developing countries due to poor purchasing power of the consumers and unsatisfactory delivery infrastructure, especially in the rural areas. Therefore, diversified food uses and biofortified crops provide cost-effective and sustainable options to reduce micronutrient malnutrition in such areas. Dietary diversity is a qualitative measure of food consumption that reflects household access to a variety of foods. However, getting people to eat more nutrient-rich fewer staples is very challenging, and affordability is constrained. Biofortification is the process of increasing the content and bioavailability of essential vitamins and minerals in staple crops, through plant breeding to improve nutritional status. This approach contributes to improving the diet quality of populations, and can be viewed as integral part of dietary diversity. Biofortification program has initiated the development and dissemination of 
improved crop cultivars with elevated levels of many micronutrients in several crops including pearl millet (Yadava et al. 2017). Genetic enhancement in pearl millet for increased micronutrients has focused grain $\mathrm{Fe}$ and $\mathrm{Zn}$ using conventional and molecular breeding approaches and the progress achieved is reviewed here.

\subsection{Genetic Enhancement of Grain Quality Traits}

The aim of core breeding has long been to increase yield potential of cultivars and has largely been accomplished by increasing grain yield through heterosis and building of resistance genes for various diseases and pests in cross-pollinated crops. Recent addition of improving grain nutritional traits is assumed to be newer area for breeders. Conventional breeding methods in combination with advanced phenotyping and biotechnological approaches enable desirable changes to improve the micronutrient content of new cultivars. The available natural genetic variation for essential nutrient content should permit breeding programs to improve the levels of minerals and vitamins in crops (Cakmak 2008; Monasterio and Graham 2000). In pearl millet, a major initiative toward the development of high-iron pearl millet cultivars has been taken involving the International Crops Research Institute for the Semi-Arid Tropics (ICRISAT) and National Agricultural Research System (NARS) partners from the public and private sector. Such efforts can only be successful and sustainable when biofortified cultivars maintain high yield productivity along with higher nutrient contents offering a benefit to both grower and consumer. Interestingly, the micronutrient traits in pearl millet (like in other cereals) are relatively more stable than grain yield and its components (Satyavathi et al. 2015; Kanatti et al. 2014a).

The extent of genetic variation for grain Fe and $\mathrm{Zn}$ contents in germplasm collection, identification of seed-mineral dense germplasm, nature of genotype $\times$ environment interaction, relationships between grain minerals and agronomic traits and genetic control of micronutrients would determine breeding efficiency for developing grain mineral dense cultivars. Therefore, a detailed insight is provided here to assess the progress made so far in these areas.

\subsubsection{Targeted Micronutrients and Extent of Genetic Variation}

Although pearl millet grain is rich in minerals and proteins, the severity of $\mathrm{Fe}$ and $\mathrm{Zn}$ deficiency and its associated health consequences show greater importance of these two micronutrients than others. The natural variation for grain $\mathrm{Fe}$ and $\mathrm{Zn}$ contents has been extensively studied in pearl millet (Table 4.1). In general, the spread of variation for grain Fe content was larger than the grain $\mathrm{Zn}$ content in various types of genetic materials that includes breeding progenies, populations, and cultivars. For example, too ambitious variation was observed in some studies: the grain 
Table 4.1 Iron $(\mathrm{Fe})$ and Zinc $(\mathrm{Zn})$ content in high-Fe seed parents progenies (data are mean of 6 seasons at Patancheru)

\begin{tabular}{|c|c|c|c|c|}
\hline \multirow[b]{2}{*}{ Advanced breeding line } & \multicolumn{2}{|c|}{$\begin{array}{l}\text { XRF Fe content } \\
\left(\mathrm{mg} \mathrm{kg}^{-1}\right)\end{array}$} & \multicolumn{2}{|c|}{$\begin{array}{l}\text { XRF Zn } \\
\text { content } \\
\left(\mathrm{mg} \mathrm{kg}^{-1}\right)\end{array}$} \\
\hline & Mean & Range & Mean & Range \\
\hline $\begin{array}{l}\text { (EEBC S1-407-1-B-B-B-B-B-1-B-1-B-10-1 × B-bulk } \\
(3981-3989 \text { G))-2-4-1 }\end{array}$ & 82 & $57-101$ & 51 & $35-67$ \\
\hline $\begin{array}{l}\text { (EEBC S1-407-1-B-B-B-B-B-1-B-1-B-13-1 × B-bulk } \\
(3981-3989 / S 06 \text { G1))-1-2-3 }\end{array}$ & 81 & $68-104$ & 50 & $29-65$ \\
\hline $\begin{array}{l}\text { (EEBC S1-407-1-B-B-B-B-B-1-B-1-B-5-1 × B-bulk } \\
(3981-3989 / \text { S06 G1))-2-1-3 }\end{array}$ & 88 & $61-113$ & 55 & $31-81$ \\
\hline$($ ICMB $04888 \times$ ICMB 02333)-1-1-3-2 & 77 & $68-88$ & 49 & $33-64$ \\
\hline $\begin{array}{l}\text { (ICMB 95111 × EEBC } \\
\text { S1-407-1-B-B)-17-3-1-B-B-B-B-4-B × 3981-4011 G2\}-1-4-2 }\end{array}$ & 90 & $76-104$ & 57 & $40-72$ \\
\hline (ICMB $99555 \times$ ICMB 99111)-2-1-1-B-B-B-1 & 81 & $55-101$ & 46 & $33-57$ \\
\hline$(\mathrm{NC}$ D2 BC7F4-34-3-1-2-B-2-B $\times$ EEBC 407)-12-1-2 & 86 & 54-97 & 56 & $36-75$ \\
\hline (NC D2 BC7F4-34-3-1-2-B-2-B $\times$ EEBC 407)-4-2-2-2 & 86 & $62-102$ & 52 & $35-66$ \\
\hline $\begin{array}{l}\{[(843 \mathrm{~B} \times \text { ICTP } 8202-161-5)-20-3-B-B-3 \times \text { B-bulk }]- \\
2-B-9 \times[(\text { ICMB } 96555 \times \text { LaGrap C2 S1-32-1)-10 } \times \text { IP } \\
14758-2-1]-8-2\}-1-1-1-2\end{array}$ & 86 & $80-92$ & 46 & $34-53$ \\
\hline $\begin{array}{l}\{[(\text { BESCBPT/91-40 } \times \text { SPF3/S91-3)-1-2-2-3 } \times \text { B-bulk]-8-1-1- } \\
\text { 3-B-B-B-B-3-1 × B-bulk (3981-4011/S06G1) \}-1-3-2 }\end{array}$ & 104 & $79-123$ & 57 & $38-82$ \\
\hline AIMP 92901 S1-15-1-2-3-B-3-B-9-2-1 & 92 & $71-119$ & 53 & $30-78$ \\
\hline AIMP 92901 S1-296-2-1-1-4-2-B-7-3-1 & 102 & $90-118$ & 57 & $42-72$ \\
\hline HHVBC Tall S1-51-1-P1-3-B & 100 & $77-129$ & 53 & $38-62$ \\
\hline ICMR 312 S1-59-1 & 97 & $83-118$ & 60 & $46-77$ \\
\hline ICMV 221 S1-366 & 86 & $80-92$ & 58 & $42-73$ \\
\hline ICMV 96490-S1-15-1-2-2-1-2 & 115 & $95-138$ & 62 & $41-77$ \\
\hline ICTP 8203 S1-386 & 98 & $84-124$ & 61 & $41-83$ \\
\hline
\end{tabular}

Fe and $\mathrm{Zn}$ contents ranged from 40 to $580 \mathrm{mg} \mathrm{kg}^{-1}$ and from 10 to $66 \mathrm{mg} \mathrm{kg}^{-1}$, respectively (Jambunathan and Subramanian 1988). But looking at the size of experimental materials (test entries) that were studied in these studies, varied and only few studies had adequate number of test entries to investigate the variation for grain $\mathrm{Fe}$ and $\mathrm{Zn}$ contents.

Velu et al. (2007) reported large variability for grain Fe content (30.1$75.7 \mathrm{mg} \mathrm{kg}^{-1}$ ) and $\mathrm{Zn}$ content (24.5-64.8 $\mathrm{mg} \mathrm{kg}^{-1}$ ) in pearl millet breeding lines. Rai et al. (2012) also reported large variation for both Fe and $\mathrm{Zn}$ contents: Fe ranging from 18 to $97 \mathrm{mg} \mathrm{kg}^{-1}$ and $\mathrm{Zn}$ varying from 22 to $69 \mathrm{mg} \mathrm{kg}^{-1}$ in the advance breeding lines; and $\mathrm{Fe}$ ranging from 52 to $135 \mathrm{mg} \mathrm{kg}^{-1}$ and $\mathrm{Zn}$ ranging from 40 to $92 \mathrm{mg} \mathrm{kg}^{-1}$ in the population progenies. Similarly, two to threefold variation among germplasm collections was reported for both Fe (51-121 $\mathrm{mg} \mathrm{kg}^{-1}$ ) and $\mathrm{Zn} \mathrm{(46-}$ $87 \mathrm{mg} \mathrm{kg}^{-1}$ ) contents (Rai et al. 2014). Interestingly, most of the high Fe and $\mathrm{Zn}$ accessions were from Togo and Ghana that had Fe content of 95-121 mg kg-1 and Zn content of 59-87 mg kg-1 indicating iniadi germplasm as a valuable germplasm resource for genetic improvement of $\mathrm{Fe}$ and $\mathrm{Zn}$ contents in pearl millet. 
The magnitude of variation for these micronutrients among the released and commercial cultivars (18 OPVs and 122 hybrids) in India was studied (Rai et al. 2016). OPVs had a Fe range of 42-67 $\mathrm{mg} \mathrm{kg}^{-1}$, and $\mathrm{Zn}$ range of $37-52 \mathrm{mg} \mathrm{kg}^{-1}$ with ICTP 8203 having the highest Fe content $\left(67 \mathrm{mg} \mathrm{kg}^{-1}\right)$ followed by ICMV 221 $\left(61 \mathrm{mg} \mathrm{kg}^{-1}\right)$ and AIMP $92901\left(56 \mathrm{mg} \mathrm{kg}^{-1}\right)$. ICTP 8203 had highest level of Zn content $\left(52 \mathrm{mg} \mathrm{kg}^{-1}\right)$, followed by ICMV 221 and AIMP $92901\left(45-46 \mathrm{mg} \mathrm{kg}^{-1}\right)$, whereas Fe content in hybrids varied from 46 to $56 \mathrm{mg} \mathrm{kg}^{-1}$ and $\mathrm{Zn}$ content from 37 to $44 \mathrm{mg} \mathrm{kg}^{-1}$. Four high Fe and $\mathrm{Zn}$ hybrids were identified as Ajeet 38, Proagro XL 51, PAC 903, and 86M86 with 55-56 mg kg-1 Fe content and with 39-41 $\mathrm{mg} \mathrm{kg}^{-1}$ $\mathrm{Zn}$ content. These high $\mathrm{Fe}$ and $\mathrm{Zn}$ cultivars can be readily utilized for expanded cultivation and can also be proposed to be included in development programs.

\subsubsection{Micronutrient Phenotyping Protocols}

Since pearl millet is a highly cross-pollinated crop, three types of seed samples (selfed, sibbed, and open-pollinated seeds) can be used for the micronutrient analysis. However, open-pollinated seed sampling is the best choice in terms of costeffectiveness and reliable estimation, provided Al contents of samples are monitored for possible dust contamination (Rai et al. 2015a). The availability of low cost and quick throughput analytical methods for micronutrient screening is a prerequisite for successful biofortification breeding. Although variety of instrumental techniques have been used for plant mineral determination so far, breeders presently rely heavily on Atomic Absorption Spectrometry (AAS) and Inductively Coupled Plasma Optical Emission Spectrometry (ICP). Almost all the analytical laboratories of the National Agricultural Research System (NARS) in India are using AAS and very few use ICP. When a large number of samples are to be screened for a given micronutrient, a simple, rapid, and cost-efficient method can surely save the time and resources, and can increase the breeding efficiency to enhance genetic gain for that trait. Recently, Energy-Dispersive X-ray Fluorescence (XRF) has been used for plant sample analysis. XRF is a relatively non-destructive method for grain Fe and $\mathrm{Zn}$ contents estimation and has now been validated for pearl millet (Paltridge et al. 2012). Setting up this table-top machine requires little recurring expenditure and provides non-destructive analysis of 300 samples per day at the cost of <USD 2.0 per sample compared to the ICP method (>18 USD/sample) which takes a month time (Rai et al. 2012). High-throughput XRF facility was established in 2010 at ICRISAT, Patancheru, which enables handling a large number of breeding lines at ICRISAT and its partners' center (15,000-20,000 grain samples per year). Efficiency of XRF over ICP for high-throughput Fe and Zn estimation in pearl millet grain was demonstrated with large samples from several trials (Govindaraj et al. 2016a, b). This study showed that highly significant and positive correlations between ICP and XRF $\left(r=>0.80^{* *} ; p<0.01\right)$ for both micronutrients provide the reliable screening technique and breeders can rapidly discard low Fe/Zn genotypes while generation advancement. 


\subsubsection{Genetics of Grain Iron and Zinc Contents}

Understanding the nature of gene action and inheritance patterns of grain micronutrient is crucial for breeders to develop effective biofortification breeding strategies. Several studies in pearl millet using different mating designs showed that the inheritance of grain $\mathrm{Fe}$ and $\mathrm{Zn}$ contents is largely attributed to additive genetic variance with higher magnitude of heritability, explaining the simple inheritance pattern and simple selection for these micronutrients to be effective (Velu 2006; Arulselvi et al. 2007; Gupta et al. 2009; Govindaraj et al. 2016a, b). In general, variability among the hybrids attributable to general combining ability $\left(\sigma^{2} \mathrm{GCA}\right)$ was 3-4 times greater than the variability attributable to specific combining ability ( $\left.\sigma^{2} \mathrm{SCA}\right)$ for Fe and $\mathrm{Zn}$ contents. This proposition of $\sigma^{2} \mathrm{GCA}$ over $\sigma^{2} \mathrm{SCA}$, in turn, contributes to greater predictability ratio which was always closer to unity for both micronutrients. This indicated that the GCA effect for both $\mathrm{Fe}$ and $\mathrm{Zn}$ contents were predominantly under additive genetic control in pearl millet (Velu et al. 2011; Rai et al. 2012; Govindaraj et al. 2013; Kanatti et al. 2014a). Highly significant and positive correlations between hybrid performance per se and mid-parental values provided further support for these micronutrients being largely under additive genetic control. In contrary, another study reported predominance of non-additive genetic variance for these micronutrients (Arulselvi et al. 2006).

Differences in reciprocal crosses is a widely used method for estimating maternal effects in trait inheritance. The differences between the direct crosses and reciprocal crosses were non-significant both for the Fe and $\mathrm{Zn}$ contents both in genotypes with high- and low-content genetic backgrounds (Kanatti et al. 2018). This indicated that genetics of both the micronutrients are controlled by nuclear determinants of male and female parents which showed the relatively greater importance of both nuclear than cytoplasmic contribution. Further, genetic studies revealed the high grain Fe and $\mathrm{Zn}$ parents had positive and significant GCA effects, while parents with low grain Fe and $\mathrm{Zn}$ had significant negative GCA effects (Govindaraj et al. 2013; Kanatti et al. 2014a). This pattern of genetic control suggested that the selection for higher grain micronutrients should be commenced in earlier generation while agronomic superiority can be selected in later generations. Interestingly, unlike yield traits, inbreeding has no adverse effect on micronutrient content in pearl millet (Rai et al. 2017).

\subsubsection{Conventional Breeding}

\subsubsection{Source of Higher Fe and Zn Contents}

Evaluations have been undertaken to identify germplasm sources for high Fe and Zn grain contents. Seed parent and restorer lines of hybrids and advanced breeding lines developed from a diverse range of germplasm have been screened to identify 
existing sources for high Fe/Zn in elite agronomic backgrounds. Consequently, large variability was observed for both micronutrients among seed parents progenies and ten lines have been identified having very high Fe and $\mathrm{Zn}$ contents (Table 4.1). Except for two progenies that involved a NCD2 (Nigerian Composite Dwarf) progeny as one of the parents in the cross, all other progenies were derived from crosses that had both parents developed from iniadi germplasm, with a progeny from Extraearly B-composite (EEBC) involved in most of the crosses. These identified progenies with such high levels of Fe and $\mathrm{Zn}$ contents would serve as ready-to-use donor source for B $\times$ B crosses to develop counterpart A-line. Similarly, selected sources from restorer progenies for high-Fe and $\mathrm{Zn}$ are given in Table 4.2. Previous evaluation studies in pearl millet have also shown that breeding lines, hybrid parents, and improved populations having high $\mathrm{Fe}$ and $\mathrm{Zn}$ contents were often based largely on iniadi germplasm (Velu et al. 2011; Govindaraj et al. 2013; Kanatti et al. 2014a; Rai et al. 2015b). Iniadi refers to an early-maturing and large-seeded landrace found in the adjoining parts of Togo, Ghana, Benin, and Burkina Faso and such source also known by various local names such as nara, nata, ignati, ignate, ignie, misse, and likoun (Andrews and Kumar 1996).

The positive and significant correlation between per se performance of the parents for micronutrients and their GCA effects indicates that per se performance of the parents, in general, is a good indicator of hybrid performance (Rai et al. 2012).

Table 4.2 Iron (Fe) and Zinc ( $\mathrm{Zn})$ content in high-Fe restorer parents progenies (data are mean of $4-8$ seasons at Patancheru)

\begin{tabular}{l|l|l|l|l}
\hline \multirow{2}{*}{ Advanced breeding line } & \multicolumn{2}{l|}{$\begin{array}{l}\text { XRF Fe content } \\
\left(\mathrm{mg} \mathrm{kg}^{-1}\right)\end{array}$} & \multicolumn{2}{l}{$\begin{array}{l}\text { XRF Zn content } \\
\left(\mathrm{mg} \mathrm{kg}^{-1}\right)\end{array}$} \\
\cline { 2 - 6 } & Mean & Range & Mean & Range \\
\hline AIMP 92901 S1-15-1-2-3-B-3-B-9-2-1 & 92 & $71-119$ & 53 & $30-78$ \\
\hline AIMP 92901 S1-296-2-1-1-4-2-B-7-3-1 & 102 & $90-118$ & 57 & $42-72$ \\
\hline HHVBC Tall S1-51-1-P1-3-B & 100 & $77-129$ & 53 & $38-62$ \\
\hline ICMR 312 S1-59-1 & 97 & $83-118$ & 60 & $46-77$ \\
\hline ICMV 221 S1-366 & 86 & $80-92$ & 58 & $42-73$ \\
\hline ICMV 96490-S1-15-1-2-2-1-2 & 115 & $95-138$ & 62 & $41-77$ \\
\hline ICTP 8203 S1-386 & 98 & $84-124$ & 61 & $41-83$ \\
\hline LaGrap C2-S1-14-4-1-3-4-4 & 89 & $72-112$ & 57 & $43-70$ \\
\hline MRC HS-130-2-2-1-B-B-3-B-B-B-1-3-1 & 110 & $93-128$ & 64 & $42-76$ \\
\hline SDMV 90031-S1-11-1-1-3-3-B-4-B-2-1-B & 87 & $64-107$ & 57 & $38-79$ \\
\hline (EERC-HS-8)-B-2-1-2-1 & 100 & $85-119$ & 48 & $28-78$ \\
\hline (MC 94 C2-S1-3-1-3-3-1-2-1 $\times$ ICMR & 92 & $87-96$ & 51 & $36-69$ \\
\hline 312 S1-3-2-3-2-1-1-B-B)-B-46-P1-1 & & & & \\
\hline (MC 94 C2-S1-3-1-3-3-1-2-1 $\times$ SDMV & 76 & $65-87$ & 62 & $44-74$ \\
\hline 90031 S1-3-3-2-2-2-2-2)-B-8-2-1 & & & & \\
\hline (MC 94 C2-S1-3-2-2-2-1-3-B-B $\times$ AIMP & 79 & $66-105$ & 54 & $41-67$ \\
\hline 92901 S1-488-2-1-1-4-B-B)-B-30-1-3 & & & & \\
\hline [(IPC 1617 $\times$ SDMV 90031-S1-84-1-1-1-1) × AIMP & 90 & $69-121$ & 59 & $36-79$ \\
\hline 92901 S1-296-2-1-1-3-B-1]-4-4-2-1 & & & & \\
\hline
\end{tabular}


Using both of these parameters, 863B, ICMB 98222, ICMB 99222, ICMB 02333, ICMB 04999, IPC 1650, IPC 843, IPC 774, IPC 1178, IPC 689, and IPC 735 were identified as moderate-to-high Fe lines and the best general combiners for use in hybrid breeding. The above results suggest that population progenies with higher levels $\left(>70 \mathrm{mg} \mathrm{kg}^{-1}\right)$ are available as donor sources for further genetic enhancement of these micronutrients, and lines with high $\mathrm{Fe}$ and $\mathrm{Zn}$ can be identified in breeding material with elite genetic backgrounds for their direct use in hybrid parents development.

\subsubsection{Genotype by Environment Interaction}

Interaction between genetic and environmental factors $(\mathrm{G} \times \mathrm{E}$ interactions $)$ affects expression of any quantitative trait. Early breeding efforts in biofortification were hindered by gaps regarding appropriate methods for micronutrient traits assessment and the effects of variable environmental factors on biofortified traits. This was primarily due to perception that biofortified traits are qualitative rather than quantitative in nature. There are now evidences that there are significant $\mathrm{G} \times \mathrm{E}$ interactions in expression of biofortified traits (Reynolds et al. 2005; Govindaraj et al. 2013; Kanatti et al. 2014a). Recent studies have shown significant role of environment and genotype $\times$ environment $(\mathrm{G} \times \mathrm{E})$ interaction in determining the levels of grain $\mathrm{Fe}$ and $\mathrm{Zn}$ contents in pearl millet (Rai et al. 2016). While $\mathrm{G} \times \mathrm{E}$ interactions for $\mathrm{Fe}$ and $\mathrm{Zn}$ appear to play an important role, the genetic variance contribution was twice than that due to $\mathrm{G} \times \mathrm{E}$ for these micronutrients (Govindaraj et al. 2016b). Most studies in pearl millet showed that $\mathrm{G} \times \mathrm{E}$ interactions accounted for $10-30 \%$ of the variation for $\mathrm{Fe}$ and $\mathrm{Zn}$ contents and it is possible to identify the genotypes with high and stable mineral content across environments.

Complexity of soil micronutrient status may partly contribute to environmental interaction for expression of these traits. Analyzing soil and grain samples from the target environments explains the underlying factors of $\mathrm{G} \times \mathrm{E}$ interactions and the magnitude of micronutrient trait expression. A large number of multi-location evaluations under biofortification program at ICRISAT indicated that all the locations had sufficient levels of $\mathrm{Fe}$ and $\mathrm{Zn}$ and other important minerals and did not establish relationship of micronutrient content in the grain with the soil available micronutrient status (Govindaraj et al. 2013; Kanatti et al. 2014a). Differences in soil Fe and $\mathrm{Zn}$ contents between contrast environment (rainy and summer) were also not reflected in the grain Fe and Zn contents (Gupta et al. 2009) indicating that soil micronutrient status above critical limits has no influence on grain mineral contents. In spite of $\mathrm{G} \times \mathrm{E}$ challenges, there is a growing evidence that breeding for increased levels of micronutrient across environment is feasible with high yield in pearl millet because of positive correlation between $\mathrm{Fe}$ and $\mathrm{Zn}$ contents and reported higher heritability of these micronutrients than grain yield (Govindaraj 2011; Govindaraj et al. 2016b). 


\subsubsection{Trait Association}

Biofortification aims to address nutrient deficiencies as an integral part of core breeding program, but there is need to understand the potential impact of higher micronutrient contents on other important traits. For instance, selection for increased micronutrient content may be expected to negatively affect yield or other important agronomic and end-use characters. This happens if genes that increase micronutrient content are linked with genes that have a deleterious effect on other desired traits, or it could occur as a consequence of negative trait associations. Association between grain $\mathrm{Fe}$ and $\mathrm{Zn}$ has largely been studied in pearl millet and other crops and highly positive and significant correlations between Fe and $\mathrm{Zn}$ have been revealed (Gregorio et al. 2000; Ozkan et al. 2007; Velu et al. 2011). The correlations between Fe and $\mathrm{Zn}$ contents in pearl millet varied from 0.43 to 0.97 (Velu et al. 2011; Rai et al. 2012; Govindaraj et al. 2013 and Kanatti et al. 2014b). Such high positive correlations among micronutrients indicate that improvement in Fe content may simultaneously improve the $\mathrm{Zn}$ content owing to similar transport and chelation process affecting the accumulation of both Fe and $\mathrm{Zn}$ contents in pearl millet seeds. Studies also reported significant positive association of $\mathrm{Fe}$ and $\mathrm{Zn}$ contents with grain weight in pearl millet (Velu et al. 2007, 2008a, b; Kanatti et al. 2014b), while other studies in pearl millet observed non-significant association grain $\mathrm{Fe}$ and $\mathrm{Zn}$ contents with 1000-grain weight (Gupta et al. 2009 and Rai et al. 2012; Yadav et al. 2016). Thus, the genetic enhancement of these micronutrients is possible without compromising on grain size.

The Fe and $\mathrm{Zn}$ contents had negative and mostly non-significant correlation with grain yield in pearl millet (Rai et al. 2016; Kanatti et al. 2014b; Yadav et al. 2016). In those studies where correlation was negative, it was weak enough in the magnitude, indicating that if these were the results of adverse genetic associations, high-yielding hybrids with high Fe and Zn contents can be bred by making selection for these traits in larger segregating populations and progenies as compared to those used for breeding for grain yield alone. These weak negative relationships resulted from dilution effects when dealing with selfed seeds where grain yield was reduced and micronutrients were overestimated (Govindaraj et al. 2012). On the other side, this trend could be of unidirectional selections as most correlations so far reported are in those lines/cultivars that were bred exclusively for yield (as target trait). Hence, further research involving random sets of lines derived from random-mated populations constituted from crosses between high-Fe/Zn and low$\mathrm{Fe} / \mathrm{Zn}$ lines but high yielding is required to examine the magnitude and direction of association of these micronutrients with grain yield. Commercial hybrids (86M86, XL51, and Ajeet 38) bred for higher yield and widely cultivated in India have higher yield and higher Fe content (>50 mg kg-1 $\mathrm{Fe}$ ) among released cultivars shows the possibility of combining grain yield and micronutrient in cultivars (Rai et al. 2016). 


\subsubsection{Population Improvement}

Pearl millet is a highly cross-pollinated crop with $70-80 \%$ outcrossing and development of open-pollinated varieties (OPVs) as commercial cultivar is an option. Both $\mathrm{Fe}$ and $\mathrm{Zn}$ contents being largely under additive genetic control, inter and intra-population improvement is highly effective. Although individual plant selection is not very effective for grain yield, $S_{1}$ progenies selection is an effective population improvement method for grain yield in pearl millet. A study confirmed the efficiency of single plant selection for Fe and $\mathrm{Zn}$ contents in four diverse OPVs (ICTP 8203, IBV 3, AIMP 92901, and ICMR 312) (Govindaraj et al. 2012). Selfed grains produced from $S_{0}$ plants and $S_{1}$ progenies were assessed for Fe and $\mathrm{Zn}$ content and correlation between the $S_{0}$ plants and the mean of $S_{1}$ progenies across environments was positive and highly significant in all four populations, both for Fe $(r=0.58-0.75)$ and $\mathrm{Zn}$ content $(r=0.61-0.73)$. Therefore, individual plant progeny selection is effective for both Fe and $\mathrm{Zn}$ contents for intra-population improvement as followed for grain yield improvement. For inter- and intra-population improvement, a study revealed that one cycle of selective random matting had improved grain $\mathrm{Fe}$ and $\mathrm{Zn}$ in $\mathrm{C}_{1}$ over $\mathrm{C}_{0}$ bulks with an increase of $8 \%$ (Fe and $\mathrm{Zn}$ )) in AIMP 92901 and ICMR 312 (Govindaraj 2011). Interestingly, such selection for high $\mathrm{Fe}$ and $\mathrm{Zn}$ significantly increased 1000 -grain mass by $5-14 \%$ in these two populations and had no adverse effect on grain yield. Similarly, ICTP8203-10-2, a population developed by recombining $11 \mathrm{~S} 3$ progenies, had $71 \mathrm{mg} \mathrm{kg}^{-1} \mathrm{Fe}$ content (9\% higher than original) and $2.2 \mathrm{t} \mathrm{ha}^{-1}$ grain yield (11\% higher than original). Based on national testing, this population was released as 'Dhanashakti' and is the first biofortified crop cultivar for Fe in public domain in India and few other highFe OPVs are under development at ICRISAT with much higher Fe and Zn contents (Rai et al. 2014).

\subsubsection{Hybrid Breeding}

The higher level of outcrossing and heterosis supported with availability of commercially viable cytoplasmic-nuclear male sterility system, hybrids breeding has been very effective in increasing pearl millet productivity in India. Heterosis, defined as the superiority in performance of hybrids over its parents (mostly higher parent), is largely explained either due to dominance or over-dominance effects. There is no better-parent heterosis for $\mathrm{Fe}$ and $\mathrm{Zn}$ reported so far in pearl millet since predominance of additive gene action in the genetic control of these traits, which indicates that there would be little opportunity to exploit better-parent heterosis for improving these micronutrients. However, development of hybrids with high $\mathrm{Fe}$ and $\mathrm{Zn}$ contents highly require incorporation of high $\mathrm{Fe}$ and $\mathrm{Zn}$ genes into both parental lines of hybrids where the mid-parent heterosis of a hybrid is gradually increased. Therefore, to breed high iron/zinc hybrids, all potential parental lines should be characterized for these micronutrients and only selected lines should be hybridized. 
Unlike grain yield, performance per se of lines is significantly and positively correlated with general combining ability for Fe and Zn in pearl millet, implying the lines selected for high $\mathrm{Fe}$ and $\mathrm{Zn}$ will also be high general combiners for these micronutrients (Velu et al. 2011; Govindaraj et al. 2013; Kanatti et al. 2014a, 2016). Development of inbred lines with high $\mathrm{Fe}$ and $\mathrm{Zn}$ depends on the level of and variability for these micronutrients in the base population (whether $\mathrm{F}_{2} \mathrm{~s}$ or OPVs or composites), and on the magnitude, direction, and pattern of inbreeding effects. It has been observed that inbreeding had either no significant effect or had marginally increased both micronutrients (Rai et al. 2017). In contrast to the low heritability and inbreeding depression of grain yield, micronutrient contents are highly heritable and hybrids can be readily improved through hybrid parents breeding. So far, the best source of high Fe and $\mathrm{Zn}$ contents in pearl millet is found to be iniadi germplasm (Velu et al. 2011; Rai et al. 2012; Govindaraj et al. 2013). Considering the additive gene action and one source of germplasm genes introgressed in both parental lines, it is expected to reduce genetic diversity between male and female groups for other important traits. This will also lead to reduced heterosis for yield traits, which are predominantly under non-additive gene control. Thus, genomics approaches for selective introgression of genes for $\mathrm{Fe}$ and $\mathrm{Zn}$ contents in the parental lines without disrupting the diversity for other traits can play a major role in future biofortification breeding. New sources, other than iniadi, of Fe and $\mathrm{Zn}$ contents in the germplasm collections are also being explored at ICRISAT for genetic diversification for high Fe and Zn. ICRISAT and NARS have developed several biofortified seed and restorer parents with elite agronomic backgrounds in diverse cytoplasmic systems. The Fe content in these seed parents is $69-110$ and $42-55 \mathrm{mg} \mathrm{kg}^{-1} \mathrm{Zn}$ content while restorer had $74-110 \mathrm{mg} \mathrm{kg}^{-1} \mathrm{Fe}$ and $41-62 \mathrm{mg} \mathrm{kg}^{-1}$ Zn (Table 4.3).

So for biofortification breeding at ICRISAT and NARS is intensively supported by HarvestPlus Challenge Program of the CGIAR which set Fe targets for pearl millet as $77 \mathrm{mg} \mathrm{kg}^{-1}$ with increment of $30 \mathrm{mg} \mathrm{kg}^{-1}$ over first pearl millet variety (WC-C75). However, a recent study reported baseline for Fe content is $42 \mathrm{mg} \mathrm{kg}^{-1}$ among hybrids and thus target would be $72 \mathrm{mg} \mathrm{kg}^{-1}$ (Rai et al. 2016). Besides using parental lines with high $\mathrm{Fe}$, hybrids being developed with these targets are being tested at national level. A special hybrid trial at national level is being conducted to encourage mainstreaming of this trait in public and private sector breeding programs. In addition, many more hybrids have been identified (Rai et al. 2016) and are in pipeline for testing. It is important to note that higher adoption of biofortified pearl millet hybrids/varieties in a long run largely depend on higher Fe/Zn contents coupled with high yield, downy mildew resistance and drought tolerance.

\subsubsection{Improved Cultivars}

Identification of appropriate germplasm and populations with highest $\mathrm{Fe}$ and $\mathrm{Zn}$ contents is very important for demonstrating the biofortification breeding. Use of such materials would continue until parental lines with higher Fe and Zn contents 
Table 4.3 High-iron seed and restorer parents developed at ICRISAT (data are mean of four seasons)

\begin{tabular}{|c|c|c|c|c|c|}
\hline Line & $\begin{array}{l}50 \% \text { flowering } \\
\text { (days) }\end{array}$ & $\begin{array}{l}\text { XRF Fe content } \\
\left(\mathrm{mg} \mathrm{kg}^{-1}\right)\end{array}$ & $\begin{array}{l}\text { XRF Zn content } \\
\left(\mathrm{mg} \mathrm{kg}^{-1}\right)\end{array}$ & $\begin{array}{l}\text { 1000-grain } \\
\text { weight }(\mathrm{g})\end{array}$ & CMS \\
\hline \multicolumn{6}{|l|}{ Seed parents } \\
\hline ICMA/B 1501 & 39 & 76 & 42 & 13.2 & A4 \\
\hline ICMA/B 1502 & 43 & 92 & 50 & 13.6 & A1 \\
\hline ICMA/B 1503 & 43 & 69 & 43 & 15.0 & A4 \\
\hline ICMA/B 1504 & 47 & 97 & 55 & 15.5 & A1 \\
\hline $\begin{array}{l}\text { ICMA/B } 1505 \\
(15222)\end{array}$ & 41 & 110 & 55 & 15.5 & A1 \\
\hline $\begin{array}{l}\text { ICMA/B } 1506 \\
(15444)\end{array}$ & 45 & 96 & 53 & 9.9 & $\mathrm{~A} 4$ \\
\hline ICMA/B 1507 & 43 & 92 & 50 & 10.1 & A4 \\
\hline ICMA/B 1508 & 53 & 73 & 44 & 15.0 & A1 \\
\hline \multicolumn{6}{|l|}{ Restorer parents } \\
\hline ICMR 1201 & 48 & 79 & 41 & 10.5 & A1 \\
\hline ICMR 1202 & 50 & 89 & 47 & 14.2 & A1 \\
\hline ICMR 1203 & 52 & 101 & 58 & 7.9 & A4 \\
\hline ICMR 1301 & 55 & 91 & 52 & 12.7 & A1 \\
\hline ICMR 1501 & 55 & 86 & 42 & 9.9 & A1 \\
\hline ICMR 1502 & 51 & 110 & 62 & 12.4 & A1 \\
\hline ICMR 1503 & 51 & 99 & 47 & 13.7 & A4 \\
\hline ICMR 1504 & 57 & 96 & 51 & 8.8 & A1 \\
\hline ICMR 1505 & 55 & 74 & 41 & 6.9 & A4 \\
\hline
\end{tabular}

are developed through targeted breeding for these micronutrients in high-yielding backgrounds. With partnership with NARS, improved version of ICTP8203 was released as Dhanashakti for all India level in 2014 (Rai et al. 2014), and has now been adopted by 60,000 ha. Dhanashakti has been accepted by farmers not only for $\mathrm{Fe}$ and $\mathrm{Zn}$ content, but also for higher grain yield, earliness and bold seed (Table 4.4). ICMV 221, another popular cultivar, has now been further improved for $\mathrm{Fe}$ content and is under testing. The improved version of ICMV 221 has $70 \mathrm{mg} \mathrm{kg}^{-1} \mathrm{Fe}$ content (11\% higher than ICMV 221), $58 \mathrm{mg} \mathrm{kg}^{-1} \mathrm{Zn}$ content (9\% higher than ICMV 221), and grain yield $4.2 \mathrm{t} \mathrm{ha}^{-1}$ (5\% higher than ICMV 221) (Govindaraj and Rai 2016).

Several A/B pairs with high Fe content (range $65-77 \mathrm{mg} \mathrm{kg}^{-1}$ ) have been identified with ICMA 98222 and ICMA 99222 as the best general combiner for high-Fe hybrid breeding. By exploiting these lines with advanced high-Fe breeding lines as potential restorers, several high-Fe hybrids have been developed with good yield potential. Based on multi-location and multi-year testing, two hybrids, viz., ICMH 1201 and ICMH 1301 have been identified for commercialization. ICMH 1201 had $75 \mathrm{mg} \mathrm{kg}^{-1} \mathrm{Fe}$ content and $3.6 \mathrm{t} \mathrm{ha}^{-1}$ grain yields. ICMH 1201 flowered only 3 days later than ICTP 8203 , so it fits in the early-maturity group and production system. Performance of ICMH 1301 showed $72 \mathrm{mg} \mathrm{kg}^{-1} \mathrm{Fe}$ content and $3.6 \mathrm{t} \mathrm{ha}^{-1}$ grain yield. 
Table 4.4 Performance of biofortified pearl millet cultivars for $\mathrm{Fe}$ and $\mathrm{Zn}$ content, grain yield, and time to $50 \%$ flower across environments

\begin{tabular}{|c|c|c|c|c|c|c|c|c|}
\hline \multirow[b]{2}{*}{ Cultivar } & \multicolumn{2}{|c|}{$\begin{array}{l}\text { XRF Fe content } \\
\left(\mathrm{mg} \mathrm{kg}^{-1}\right)\end{array}$} & \multicolumn{2}{|c|}{$\begin{array}{l}\text { XRF Zn content } \\
\left(\mathrm{mg} \mathrm{kg}^{-1}\right)\end{array}$} & \multicolumn{2}{|c|}{ Grain yield $\left(\mathrm{t} \mathrm{ha}^{-1}\right)$} & \multicolumn{2}{|c|}{$\begin{array}{l}50 \% \text { flowering } \\
\text { (days) }\end{array}$} \\
\hline & Mean & Range & Mean & Range & Mean & Range & Mean & Range \\
\hline Dhanashakti & 71 & $40-106$ & 40 & $18-71$ & 2.20 & $0.65-5.65$ & 45 & $40-55$ \\
\hline ICTP $8203^{a}$ & 65 & 31-94 & 40 & $19-71$ & 1.97 & $0.63-4.30$ & 45 & $38-56$ \\
\hline $\begin{array}{l}\text { ICMV } 221 \mathrm{Fe} \\
11-2\end{array}$ & 70 & $62-85$ & 58 & $53-63$ & 4.24 & $3.38-5.40$ & 43 & $40-47$ \\
\hline ICMV $221^{\mathrm{a}}$ & 63 & $59-69$ & 53 & $51-58$ & 3.98 & $3.12-4.81$ & 39 & $38-41$ \\
\hline ICMH 1201 & 75 & $47-102$ & 39 & $18-69$ & 3.58 & $1.49-6.20$ & 48 & $41-56$ \\
\hline $86{\mathrm{M} 86^{\mathrm{a}}}^{2}$ & 56 & $39-71$ & 37 & $18-61$ & 4.37 & $2.60-6.47$ & 54 & $47-64$ \\
\hline ICTP $8203^{a}$ & 71 & $50-102$ & 43 & $19-77$ & 2.58 & $1.33-5.06$ & 45 & $38-55$ \\
\hline ICMH 1301 & 77 & $31-107$ & 42 & $24-64$ & 3.26 & $1.32-7.03$ & 52 & $42-62$ \\
\hline $86{\mathrm{M} 86^{\mathrm{a}}}^{2}$ & 58 & $39-85$ & 37 & $18-56$ & 4.10 & $2.60-6.95$ & 54 & $44-64$ \\
\hline ICTP $8203^{a}$ & 75 & $40-117$ & 44 & $19-77$ & 2.46 & $1.28-6.36$ & 45 & $36-53$ \\
\hline
\end{tabular}

${ }^{\mathrm{a} C h e c k}$ entry

These hybrids are cultivated by $>30,000$ farmers using truthfully labeled seed (TLS), mostly in Maharashtra and Rajasthan. Much greater progress in breeding high-Fe hybrids with high-grain yield is expected in the near future by utilizing A- and R-lines that are being developed through targeted breeding for high-Fe content.

\subsubsection{Molecular Breeding}

\subsubsection{Availability of Molecular Markers}

Pearl millet had been a crop of limited genomic resources in the past. However, since last decade, substantial progress has been made in generation of molecular markers. Like in other crops, PCR-based simple sequence repeats (SSR) markers are the extensively used markers for various genetic and mapping studies of pearl millet due to their abundance in the genome, highly polymorphic nature and easy assay. Transcriptome projects have brought enormous information on expressed sequence tags (ESTs), which were used as targets for the identification of SSR markers known as EST-SSR markers through the computational approach thereby making the SSR marker development rapid, easy, and inexpensive. These markers were subsequently used for various genetic studies in pearl millet. PCR-based screening of a bacterial artificial chromosome (BAC) library constructed using nuclear DNA from pearl millet using five sequence-tagged site (STS), led to the identification of 6 microsatellite markers (Allouis et al. 2001). Twenty-five SSRs were isolated from bacterial artificial clones (BA Clone) of pearl millet without any sub-cloning using 3' anchored SSR primers and isolation of flanking sequences by suppression PCR (Qi et al. 2001), while screening of a small-insert partial genomic 
library with a (CT) 15 oligonucleotide probe resulted in the development of 18 SSR markers (Budak et al. 2003). Similarly, 44 markers were developed from a (CA) n-enriched small-insert genomic library (Qi et al. 2004). Yadav et al. (2007) developed 32 SSR markers for pearl millet and assessed them for polymorphism in parental lines of 4-6 mapping populations (Yadav et al. 2008). A set of 58 SSR markers was developed in pearl millet and ESTs made available (Senthilvel et al. 2008). SNPs accounted for about two-thirds of the variation while InDels accounted for one-third of the variation. This demonstrated the use of syntenic information to develop SSCP-SNP markers (Bertin et al. 2005). Subsequently, Rajaram et al. (2013) developed 99 EST-SSR markers from transcriptomics work.

\subsubsection{Linkage Maps}

A genetic/linkage map depicts the arrangement of molecular markers. Linkage map is the basic framework in different linkage groups based on the recombination frequency among the markers, which are essential for the mapping of QTL. The first RFLP linkage map in pearl millet was published by Liu et al. (1994). A linkage map consisting of seven linkage groups and a total of 181 loci was made using an intervarietal F2 population, with an average inter-marker distance of about $2 \mathrm{cM}$. Qi et al. (2004) developed an integrated consensus linkage map from the genetic maps constructed for four different crosses using 353 RFLP and 65 SSR markers. The mapping of 21 polymorphic SSR markers mapped using existing mapping populations (ICMB 841-P3 $\times 863 \mathrm{~B}-\mathrm{P} 2$ and $81 \mathrm{~B}-\mathrm{P} 8 \times \mathrm{IPC} 804)$ revealed that most EST-SSR markers map to distal regions of linkage groups to cover the previous gaps (Senthilvel et al. 2008).

A linkage map was constructed using 258 DArT and 63 SSR marker data using a RIL population from cross H 77/833-2 and PRLT 2/89-33 (Supriya et al. 2011). With an objective of developing a linkage map with more evenly distributed markers and greater marker coverage of the gaps in earlier maps, Pedraza-Garcia et al. (2010) constructed a map using 196 PCR-based DNA markers (66 SRAPs, 63 RAPDs, 27 ISSRs, 31 pearl millet, six sorghum, and three maize SSRs) of nine linkage groups with an average genetic distance of $9.2 \mathrm{cM}$ between markers. Rajaram et al. (2013) also constructed Linkage maps using 99 newly developed EST-SSR markers and previously mapped 17 EST-SSR, 53 genomic SSR, and two STS markers.

A consensus map of 174 loci $(899 \mathrm{cM})$ was developed by integrating the individual linkage maps using MergeMap, which showed a well-conserved locus order for nearly all linkage groups. The linkage maps constructed using codominant SSRs and dominant DArTs span $1748.7 \mathrm{cM}$ (ICMB $841 \times 863 \mathrm{~B}$ map consisting of 305 markers) (Kumar et al. 2016). Longest SSR-based skeleton linkage map for $\mathrm{F}_{2}$-derived $\mathrm{F}_{3}$ progenies with a length of $1018.7 \mathrm{cM}$ accommodating only 44 welldistributed markers has been reported. Large map using SSRs with map length of $748 \mathrm{cM}$ for an $\mathrm{F}_{2}$ population was reported by Gulia (2004). Liu et al. (1994) reported by the shortest $\mathrm{F}_{2}$-based map $(287.7 \mathrm{cM})$ reported so far had 181 RFLP markers. 
Yadav et al. (2004) incorporated 91 marker loci in a population of $F_{2}$ individuals, with a map length of $617.4 \mathrm{cM}$ using $(\mathrm{ICMB} 841 \times 863 \mathrm{~B})$ population. Senthilvel et al. (2008) have used the same $F_{2}$ population to obtain a map length of $677 \mathrm{cM}$ with 112 loci. Vengadessan et al. (2013) constructed a linkage map, primarily based on SSCP-SNP markers, using $188 \mathrm{~F}_{2: 3}$ mapping population progenies produced from a cross between pearl millet inbred lines having diverse parentage.

The skeleton linkage map covered $1019 \mathrm{cM}$ and it comprised of 44 markers distributed across the seven linkage groups. Average adjacent-marker intervals ranged from $14 \mathrm{cM}$ on LG1 to $38 \mathrm{cM}$ on LG6, with an overall mean of $23 \mathrm{cM}$. Rajaram et al. (2013) developed 99 new EST-SSR markers (IPES series) and constructed linkage maps of four F7 recombinant inbred populations (RIP) based on four crosses along with previously mapped EST-SSR (17), genomic SSR (53), and STS (2) markers. A total of 176 loci detected by 171 primer pairs were mapped among the four crosses. A consensus map of 174 loci $(899 \mathrm{cM})$ detected by 169 primer pairs was constructed using Merge Map to integrate the individual linkage maps.

\subsubsection{Quantitative Trait Loci (QTL)}

Development of a mapping population is the most critical factor in the construction of a molecular map. Decisions on selection of parents and mating design for the development of mapping population and the type of markers used depend upon the objectives of experiments, availability of markers, and the molecular map. An appropriate mapping population, with suitable marker system and the data analyzing software are the key rations for molecular mapping and breeding. Genetic map construction requires: appropriate mapping population; pairwise recombination frequencies calculation on population; establishment of linkage groups; estimation of map distances; and determine map order. Size of mapping population is also essential factor in mapping as limited population sizes used in many QTL detection experiments may have led to underestimation of QTL number, overestimation of QTL effects, and failure to quantify QTL interactions (Beavis 1998; Melchinger et al. 1998; Utz et al. 2000). The size of the population may be determined by the gene effect to be detected as well as the type of population. While the analysis of large population would enable the detection of small-effect QTLs, the basic purpose of mapping would be served if one can detect the major QTL with large effect and this would require, in general, a mapping population of a size 200-300 individuals.

Mapping software packages, such as Mapmaker (Lander and Botstein 1989; Lander et al. 1987), Mapmanager (Manly and Elliott 1991), and Joinmap (Stam 1993) have been developed to analyze the genetic data for map construction. These software packages use genetic data of segregating mapping populations to estimate recombination frequency followed by determination of linear arrangement of genetic markers. Different types of mapping populations that are often used in linkage mapping are: F2 population; F2-derived F3 (F2:F3) populations; Backcrosses; Doubled haploids (DHs); Recombinant Inbred Lines (RILs); and 
Near-isogenic Lines (NILs). The F2 mapping population can be developed with possible combinations of parental alleles (Lander et al. 1987). A recombinant inbred line (RIL) can be obtained from an F2 generation by successive self-pollinations using the single seed descent method (SSD) (Burr et al. 1988). The resulting inbred lines are highly homozygous and the segregation ratio for each locus tends to be 1:1 (AA:aa) representing an 'immortal' or permanent mapping family and can thus be used in experiments with replications in several environments allowing for more accurate estimates of genetic components and identification of QTL vs. environment interactions. Disadvantages of recombinant inbred lines are that at least six generations are required to obtain the line and the inability to estimate dominance effects of mapped quantitative trait loci (QTL) due to the absence of heterozygous genotypes.

In pearl millet, several F2:3 and F2:4 mapping population have been developed from diverse inbred lines of Asian, American, and African origin (Hash et al. 2002). Liu et al. (1994) developed the first F2 population of 133 individuals for the study of downy mildew. It was used by Devos et al. (2000) for comparative mapping of pearl millet with foxtail millet and rice. Further to understand the genetic control of domestication trait, Poncet et al. (2000) developed a population of 250 F2 individuals from cultivated and wild F1 hybrid ( $P$. glaucum spp. monodii). Poncet et al. (2002) developed another F2 population having 168 individuals. Yadav et al. (2002, 2004) developed two mapping population by crosses of H77/833-2 × PRLT 2/89-33 (early maturing inbred line, 150 F2 individuals) and ICMB $841 \times 863 \mathrm{~B}$ agronomically elite inbred seed parent, 106 F6 individuals (Kumar et al. 2016).

The QTL analysis is based on association between trait value and marker allele. Number of studies have been reported for detecting QTLs with traits like downy mildew (Jones et al. 1995, 2002; Gulia 2004), rust and blast (Morgan et al. 1998), drought tolerance (Yadav et al. 2002, 2003, 2004; Bhattacharjee et al. 2002; Bidinger et al. 2007; Kholová et al. 2012), flowering time (Kumar et al. 2017; Saïdou et al. 2009), panicle length (Poncet et al. 2000; Kumar et al. 2017), and 1000-grain mass (Yadav et al. 2002; Bidinger et al. 2007; Kumar et al. 2017). Research on identifying QTLs and candidate genes for elevated levels of Fe and $\mathrm{Zn}$ in pearl millet is limited at this time (Manwaring et al. 2016). A recent study has identified the QTLs for higher Fe and Zn contents in ICMB $841 \times 863 \mathrm{~B}$ cross on LG3 (Kumar et al. 2016).

\subsubsection{Marker-Assisted Selection (MAS)}

Despite the fact conventional breeding approaches will continue to make valuable aids to the genetic improvement of important traits in pearl millet, the efficiency of such concerted efforts can be increased extensively through the supplementation of MAS approaches. A number of QTL and associated markers have been identified for downy mildew resistance (Hash and Witcombe 2001; Jones et al. 2002; Hash and Witcombe 2002). NILs of H 77/833-2 introgressed with various putative QTL 
regions from PRLT 2/89-33 were used for validation of major drought tolerance QTL in the LG2 target region (Serraj et al. 2005).

The validated QTL on LG3 for higher grain Fe and Zn contents (Kumar et al. 2016) has been the target for marker-assisted breeding (MAB). Using the linked flanking markers, this QTL along with downy mildew resistance QTLs has been moved into genetic background of pollen parent of hybrid HHB 67 Improved. These double QTL introgression lines were crossed with the seed parent of HHB 67 Improved to generate HHB 67 Improved like hybrids. These QTL introgression lines along with the improved test-cross hybrids are being tested in the national testing system in India.

\subsection{Future Prospects}

Considering pearl millet adaptation traits and productivity gains in the drylands over the decades, it would continue to be an important food crop for India and subSaharan Africa. It is an ideal native food crop to expand the Indian and global food basket to meet healthy food and nutritional demand of the growing population. National policy measures such as inclusion of pearl millet under public distribution system are essential, besides promotion of pearl millet in poultry/animal feed and breweries to increase incentives to growers for higher production. Creating public awareness about the nutritional values of pearl millet is urgently needed otherwise consumers are likely to prefer non-native crops for daily energy and nutritional requirements. Major area of future focus in biofortification of pearl millet should include:

- The enhanced nutrient contents of new cultivars have to be achieved without any trade off with higher productivity. This would translate into adding one additional trait in breeding program. Micronutrient traits screening is highly expensive while dealing with larger germplasm. Thus breeding for such additional traits may delay progress for productivity traits when resources are limited to breeders. Micronutrient traits are apparently not affected by genetic erosion and involve little maintenance breeding after the genes are incorporated into elite backgrounds. With availability of XRF tool, cost of biofortification breeding will decrease over time, and micronutrient content built into the gene pool will not affect future breeding for productivity traits. In order to achieve it, a higher investment in breeding would be required on a long-term basis.

- Genomic approaches should now be an integral part of breeding program particularly for nutritional traits to use diagnostic markers given that pearl millet genome has been sequenced now (Varshney et al. 2017). Genomic markers can be used to make the biofortification breeding more efficient through markerassisted selection in near future. This would also help in improving high-yielding cultivars with low iron and zinc under wider cultivation through introgression of micronutrient genes and become essentially derived variety. 
- Seed companies have well established network and dominate the pearl millet hybrid seed market in India. Since, hybrids occupy approximately $90 \%$ of the area under improved cultivars, first-biofortified variety (OPV) has limited potential to make a mega impact. To address this, public-private partnership (PPP) model needs to be strengthened by institutional policy of nutrition commitments and special price allocation for mineral-dense seeds with subsidized rates in the markets to promote biofortified cultivars.

- ICRISAT has played a key role in diversifying the hybrid parents and its contribution to achieving higher yield gain at farm level through the PPP model. Seed companies, those have research and development division, capture more than $80 \%$ of the pearl millet hybrid seed market in India. Thus, the sustainability of biofortified pearl millet will mainly depend on mainstreaming of biofortification with seed companies, state seed corporations, ICAR institutes, and state agricultural universities. Hence, cultivar product concept of partners requires considering micronutrient as a generic trait in their breeding program and this joint effort will address development of high yielding and micronutrient rich pearl millet cultivars.

- There are good prospects for large scale on-farm field and food product demonstrations through state agricultural universities, agricultural departments and Krishi Vigyan Kendras (KVKs); large-scale production and procurements of biofortified cultivar grains for Anghanwadi (childcare center); and integration of biofortified grains in mid-day meal scheme. Several governments sponsored programs such as National Food Security Mission and Integrated Child Development Program would provide window for PDS system model to address the iron and zinc deficiency.

\section{References}

Ajetomobi JO (2008) Total factor productivity of agricultural commodities in economic community of West African States (ECOWAS): 1961-2005. In: CSAE conference 2008. Economic development in Africa held 16th-18th Mar 2008 at St. Catherine's College, Oxford

Allouis S, Qi X, Lindup S, Gale MD, Devos KM (2001) Construction of a BAC library of pearl millet, Pennisetum glaucum. Theor Appl Genet 102:1200-1205

Andrews DJ, Kumar AK (1996) Use of the West African pearl millet landrace Iniadi in cultivar development. Plant Genet Resources Newsl 105:15-22

Arulselvi S, Mohanasundram K, Selvi B, Malarvizhi P (2006) Heterosis for grain yield components and grain quality characters in pearl millet. ISMN 47:36-38

Arulselvi S, Mohanasundaram K, Selvi B, Malarvizhi P (2007) Genetic variability studies and interrelationships among nutritional quality characters, phytate phosphorus and grain yield in the seeds of pearl millet (Pennisetum glaucum (L.) R. Br.). Indian J Genet Plant Breed $67: 37-40$

Basavaraj G, Parthasarathy Rao P, Bhagavatula S, Ahmed W (2010) Availability and utilization of pearl millet in India. J SAT Agric Res 8:1-6

Beavis WD (1998) QTL analyses: power, precision and accuracy. In: Paterson AH (ed) Molecular analysis of complex traits. CRC Press, Boca Raton, FL, pp 145-161 
Bertin I, Zhu JH, Gale MD (2005) SSCP-SNP in pearl millet—a new marker system for comparative genetics. Theor Appl Genet 110:1467-1472

Bhattacharjee R, Bramel PJ, Hash CT, Kolesnikova-Allen M, Khaid IS (2002) Assessment of genetic diversity within and between pearl millet landraces. Theor Appl Genet 105:666-673

Bidinger FR, Nepolean T, Hash CT, Yadav RS, Howarth CJ (2007) Identification of QTLs grain yield of pearl millet [Pennisetum glaucum (L.) R. Br.] in environments with variable moisture during grain filling. Crop Sci 47:969-980

Budak H, Pedraza F, Cregan PB, Baenziger PS, Dweikat I (2003) Development and utilization of SSRs to estimate the degree of genetic relationships in a collection of pearl millet germplasm. Crop Sci 43:2284-2290

Burr B, Burr FA, Thompson KH, Albertson MC, Stuber CW (1988) Gene mapping with recombinant inbreds in maize. Genetics 118:519-526

Cakmak I (2008) Enrichment of cereal grains with zinc: agronomic or genetic biofortification? Plant Soil 302:1-17

Devos KM, Pittaway TS, Reynolds A, Gale MD (2000) Comparative mapping reveals a complex relationship between the pearl millet genome and those of foxtail millet and rice. Theor Appl Genet 100:190-198

Govindaraj M (2011) Genetics of grain iron and zinc concentration in pearl millet (Pennisetum glaucum (L.) R. Br.). Ph.D. thesis, Tamil Nadu Agricultural University

Govindaraj M, Rai KN (2016) Breeding biofortified pearl millet cultivars with high iron density. Indian Farm 65:53-55

Govindaraj M, Rai KN, Shanmugasundaram P, Rao AS (2012) Efficiency of single plant selection for grain iron and zinc density in pearl millet. Eur J Plant Sci Biotechnol 6:114-117

Govindaraj M, Rai KN, Shanmugasundaram P, Dwivedi SL, Sahrawat KL, Muthaiah AR, Rao AS (2013) Combining ability and heterosis for grain iron and zinc densities in pearl millet. Crop Sci 53:507-517

Govindaraj M, Rai KN, Pfeiffer WH, Kanatti A, Shivade H (2016a) Energy-dispersive X-ray fluorescence spectrometry for cost-effective and rapid screening of pearl millet germplasm and breeding lines for grain iron and zinc density. Commun Soil Sci Plant Anal 47:2126-2134

Govindaraj M, Rai KN, Shanmugasundaram P (2016b) Intra-population genetic variance for grain iron and zinc contents and agronomic traits in pearl millet. Crop J 4:48-54

Gregorio GB, Senadhira D, Htut H, Graham RD (2000) Breeding for trace mineral density in rice. Food Nutr Bull 21:383-386

Gulia SK (2004) QTL mapping for improvement of downy mildew [Sclerospora graminicola (Sacc.) J. Schroet.] resistance (DMR) in pearl millet [Pennisetum glaucum (L.) R. Br.] ICMB 89111. Ph.D thesis, Chaudhary Charan Singh Haryana Agricultural University, Hisar

Gupta SK, Velu G, Rai KN, Sumalini K (2009) Association of grain iron and zinc content with grain yield and other traits in pearl millet (Pennisetum glaucum (L.) R. Br.). Crop Improv $36: 4-7$

Hash CT, Witcombe JR (2001) Pearl millet molecular marker research. Int Sorghum Millets Newsl 42:8-15

Hash CT, Witcombe JR (2002) Gene management and breeding for downy mildew resistance. In: Leslie JF (ed) Sorghum and millets diseases. Iowa State Press, Ames, IO, pp 27-36

Hash CT, Schaffert RE, Peacock JM (2002) Prospects for using conventional techniques and molecular biological tools to enhance performance of 'orphan' crop plants on soils low in available phosphorus. Plant Soil 245:135-146

ICMR (2002) Nutrient requirements and recommended dietary allowances for Indians. Indian Council of Medical Research, New Delhi, p 83

IFAD (1999) Farmer participatory testing of technologies to increase sorghum and pearl millet production in the Sahel. www.ifad.org/grants

Jambunathan R, Subramanian V (1988) Grain quality and utilization in sorghum and pearl millet. In: Proceedings of the workshop on biotechnology for tropical crop improvement. ICRISAT, Patancheru, pp 1330-1339 
Jones ES, Liu CJ, Gale MD, Hash CT, Witcombe JR (1995) Mapping quantitative trait loci for downy mildew resistance in pearl millet. Theor Appl Genet 91:448-456

Jones ES, Breese WA, Liu CJ, Singh SD, Shaw DS, Witcombe JR (2002) Mapping quantitative trait loci for resistance to downy mildew in pearl millet: Field and glasshouse screens detect the same QTL. Crop Sci 42:1316-1323

Kanatti A, Rai KN, Radhika K, Govindaraj M, Sahrawat KL, Rao AS (2014a) Grain iron and zinc density in pearl millet: combining ability, heterosis and association with grain yield and grain size. Springerplus 3:763

Kanatti A, Rai KN, Radhika K, Govindaraj M, Sahrawat KL, Srinivasu K, Shivade H (2014b) Relationship of grain iron and zinc content with grain yield in pearl millet hybrids. Crop Improv 41:91-96

Kanatti A, Rai KN, Radhika K, Govindaraj M (2016) Tester effect on combining ability and its relationship with line performance per se for grain iron and zinc densities in pearl millet. Crop Sci 56:1-8

Kanatti A, Govindaraj M, Rai KN, Rao AS (2018) Maternal effect on grain iron and zinc densities in pearl millet. In: 1st National Genetic Congress on Genetics for Sustainable Food, Health and Nutrition Security December 14-16, IARI, New Delhi (Accepted)

Kholová J, Nepolean T, Hash CT, Supriya A, Rajaram V, Senthilvel S, Kakkera A, Yadav RS, Vadez V (2012) Water saving traits co-map with a major terminal drought tolerance quantitative trait locus in pearl millet (Pennisetum glaucum (L.) R. Br.). Mol Breed 30:1337-1353

Kumar S, Hash CT, Thirunavukkarasu N, Singh G, Rajaram V, Rathore A, Senapathy S, Mahendrakar MD, Yadav RS, Srivastava RK (2016) Mapping quantitative trait loci controlling high iron and zinc content in self and open pollinated grains of pearl millet [Pennisetum glaucum (L.) R. Br.]. Front Plant Sci 7:1636

Kumar S, Hash CT, Nepolean T, Satyavathi TS, Singh G, Mahendrakar MD, Yadav RS, Srivastava RK (2017) Mapping QTLs controlling flowering time and important agronomic traits in pearl millet [Pennisetum glaucum (L.) R. Br.]. Front Plant Sci 8:1731

Lander ES, Botstein D (1989) Mapping Mendelian factors underlying quantitative traits by using RFLP linkage maps. Genetics 121:185-199

Lander E, Green P, Abrahamson J, Barlow A, Daly MJ, Lincoln SE, Newburg L (1987) MAPMAKER: an interactive computer package for constructing primary genetic linkage maps of experimental and natural populations. Genomics 1:174-181

Liu CJ, Witcombe JR, Pittaway TS, Nash M, Hash CT, Busso CS, Gale MD (1994) An RFLPbased genetic map of pearl millet (Pennisetum glaucum). Theor Appl Genet 89:481-487

Mal B., Padulosi S. and Ravi S.B. 2010. Minor millets in South Asia: learnings from IFAD-NUS Project in India and Nepal, Rome: Bioversity International

Mani UV, Prabhu BM, Damle SS, Mani I (1993) Glycemic index of some commonly consumed foods in Western India. Asia Pac J Clin Nutr 2:111-114

Manly KF, Elliott RW (1991) RI manager, a microcomputer program for analysis of data from recombinant inbred strains. Mamm Genome 1:123-127

Manwaring HR, Bligh HFJ, Yadav R (2016) The challenges and opportunities associated with biofortification of pearl millet (Pennisetum glaucum) with elevated levels of grain iron and zinc. Front Plant Sci 7:1944

Melchinger AE, Utz HF, Schön CC (1998) Quantitative trait locus (QTL) mapping using different testers and independent population samples in maize reveals low power of QTL detection and large bias in estimates of QTL effects. Genetics 149:383-403

Monasterio I, Graham RD (2000) Breeding for trace minerals in wheat. Food Nutr Bull 21:392-396

Morgan RN, Wilson JP, Hanna WW, Ozias-Akin P (1998) Molecular markers for rust and Pyricularia leaf spot disease resistance in pearl millet. Theor Appl Genet 96:413-420

NFHS (National Family Health Survey) (2016) NFHS-4-fact sheets for key indicators. International Institute for Population Sciences, Mumbai

NIN (2003) Nutritive value of Indian foods. In: Gopalan C, Deosthale YG (eds) Nutritive value of Indian foods. National Institute of Nutrition, Hyderabad 
Ozkan H, Brandolini A, Torun A, AltIntas S, Eker S, Kilian B, Braun HJ, Salamini F, Cakmak I (2007) Natural variation and identification of microelements content in seeds of Einkorn wheat (Triticum monococcum). Dev Plant Breed 12:455-462

Paltridge NG, Palmer LJ, Milham PJ, Guild GE, Stangoulis JCR (2012) Energy-dispersive X-ray fluorescence analysis of zinc and iron concentration in rice and pearl millet grain. Plant Soil 361:251-260

Parthasarathy Rao P, Birthal PS, Reddy BVS, Rai KN, Ramesh S (2006) Diagnostics of sorghum and pearl millet grains-based nutrition in India. ISMN 46:93-96

Pedraza-Garcia F, Specht JE, Dweikat I (2010) A new PCR-based linkage map in pearl millet. Crop Sci 50:1754-1760

Poncet V, Lamy F, Devos KM, Gale MD, Sarr A, Robert T (2000) Genetic control of domestication traits in pearl millet (Pennisetum glaucum L., Poaceae). Theor Appl Genet 100:147-159

Poncet V, Martel E, Allouis S, Devos M, Lamy F, Sarr A (2002) Comparative analysis of QTLs affecting domestication traits between two domesticated $\times$ wild pearl millet (Pennisetum glaucum L., Poaceae) crosses. Theor Appl Genet 104:965-975

Qi X, Lindup S, Pittaway TS, Allouis S, Gale MD, Devos KM (2001) Development of simple sequence repeat markers from bacterial artificial chromosomes without sub cloning. BioTechniques 31(2):355-358

Qi X, Pittaway TS, Lindup S, Liu H, Waterman E, Padi FK, Devos KM (2004) An integrated genetic map and a new set of simple sequence repeat markers for pearl millet, Pennisetum glaucum. Theor Appl Genet 109:1485-1493

Rai KN, Govindaraj M, Rao AS (2012) Genetic enhancement of grain iron and zinc content in pearl millet. Quality assurance and safety of crops and food 4:119-125

Rai KN, Patil HT, Yadav OP, Govindaraj M, Khairwal IS, Cherian B, Rajpurohit BS, Rao AS, Kulkarni MP (2014) Dhanashakti: a high-iron pearl millet variety. Indian Farm 64:32-34

Rai KN, Govindaraj M, Pfeiffer WH, Rao AS (2015a) Seed set and xenia effects on grain iron and zinc density in pearl millet. Crop Sci 55:821-827

Rai KN, Velu G, Govindaraj M, Upadhyaya HD, Rao AS, Shivade H, Reddy KN (2015b) Iniadi pearl millet germplasm as a valuable genetic resource for high grain iron and zinc densities. Plant Genet Resour 13:75-82

Rai KN, Yadav OP, Govindaraj M, Pfeiffer WH, Yadav HP, Rajpurohit BS, Patil HT, Kanatti A, Rathore A, Rao AS, Shivade H (2016) Grain iron and zinc densities in released and commercial cultivars of pearl millet (Pennisetum glaucum). Indian J Agric Sci 86:11-16

Rai KN, Govindaraj M, Kanatti A, Rao AS, Shivade H (2017) Inbreeding effects on grain iron and zinc concentrations in pearl millet. Crop Sci 57:1-8

Rajaram V, Nepolean T, Senthilvel S, Varshney RK, Vadez V, Srivastava RK, Shah TM, Supriya A, Kumar S, Kumari BR, Bhanuprakash A, Narasu ML, Riera-Lizarazu O, Hash CT (2013) Pearl millet [Pennisetum glaucum (L.) R. Br.] consensus linkage map constructed using four RIL mapping populations and newly developed EST-SSRs. BMC Genomics 14(159):1-15.

Reynolds MP, Pellegrineschi A, Skovmand B (2005) Sink-limitation to yield and biomass: a summary of some investigations in spring wheat. Ann Appl Biol 146:39-49

Saïdou AA, Mariac C, Luong V, Pham JL, Bezançon G, Vigouroux Y (2009) Association studies identify natural variation at PHYC linked to flowering time and morphological variation in pearl millet. Genetics 182:899-910

Satyavathi CT, Sankar SM, Singh SP, Bhowmick P, Bhat J, Singh O, Anuradha N (2015) Stability analysis of grain iron and zinc content in pearl millet (Pennisetum glaucum (L.) R. Br). Int J Trop Agric 33:1387-1394

Senthilvel S, Jayashree B, Mahalakshmi V, Kumar PS, Nakka S, Nepolean T, Hash CT (2008) Development and mapping of simple sequence repeat markers for pearl millet from data mining of expressed sequence tags. BMC Plant Biol 8:119

Serraj R, Hash CT, Rizvi SMH, Sharma A, Yadav RS, Bidinger FR (2005) Recent advances in marker-assisted selection for drought tolerance in pearl millet. Plant Prod Sci 8:334-337 
Singh KP, Mishra A, Mishra HN (2012) Fuzzy analysis of sensory attributes of bread prepared from millet-based composite flours. LWT Food Sci Technol 48:276-282

Stam P (1993) Construction of integrated genetic linkage maps by means of a new computer package: JoinMap. Plant J 3:739-744

Supriya A, Senthilvel S, Nepolean T, Eshwar K, Rajaram V, Shaw R, Narasu ML (2011) Development of a molecular linkage map of pearl millet integrating DArT and SSR markers. Theor Appl Genet 123:239-250

Utz HF, Melchinger AE, Schön CC (2000) Bias and sampling error of the estimated proportion of genotypic variance explained by quantitative trait loci determined from experimental data in maize using cross validation and validation with independent samples. Genetics 154:1839-1849

Varshney RK, Shi C, Thudi M, Mariac C, Wallace J, Qi P, Zhang H, Zhao Y, Wang X, Rathore A, Srivastava RK, Chitikineni A, Fan G, Bajaj P, Punnuri S, Gupta SK, Wang H, Jiang Y, Couderc M, Katta MAVSK, Paudel DR, Mungra KD, Chen W, Harris-Shultz KR, Garg V, Desai N, Doddamani D, Kane N, Conner JA, Ghatak A, Chaturvedi P, Subramaniam S, Yadav OP, Berthouly-Salazar C, Hamiduo F, Wang J, Liang X, Clotault J, Upadhyaya HD, Cubry P, Rhoné B, Gueye MC, Sunkar R, Dupuy C, Sparvoli F, Cheng S, Mahala RS, Singh B, Yadav RS, Lyons E, Datta SK, Hash CT, Devos KM, Buckler E, Bennetzen JL, Paterson AH, OziasAkins P, Grando S, Wang J, Mohapatra T, Weckwerth W, Reif JC, Xi L, Vigouroux Y, Xu X (2017. Pearl millet genome sequence provides a resource to improve agronomic traits in arid environments) Nat Biotechnol 35:969-974. https://doi.org/10.1038/nbt.3943

Velu G (2006) Genetic variability, stability and inheritance of grain iron and zinc content in pearl millet (Pennisetum glaucum (L.) R. Br.). Ph.D., thesis, Tamil Nadu Agricultural University, Coimbatore, India

Velu G, Rai KN, Muralidharan V, Kulkarni VN, Longvah T, Raveendran TS (2007) Prospects of breeding biofortified pearl millet with high grain iron and zinc content. Plant Breed 126:182-185

Velu G, Rai KN, Sahrawat KL (2008a) Variability for grain iron and zinc content in a diverse range of pearl millet populations. Crop Improv 35:186-191

Velu G, Rai KN, Sahrawat KL, Sumalini K (2008b) Variability for grain iron and zinc contents in pearl millet hybrids. J SAT Agric Res 6:1-5

Velu G, Rai KN, Muralidharan V, Longvah T, Crossa J (2011) Gene effects and heterosis for grain iron and zinc density in pearl millet (Pennisetum glaucum (L.) R. Br). Euphytica 180:251-259

Vengadessan V, Rai KN, Kannan Bapu JR, Hash CT, Bhattacharjee R, Senthilvel S, Vinayan MT, Nepolean T (2013) Construction of genetic linkage map and QTL analysis of sink-size traits in pearl millet (Pennisetum glaucum). ISRN Genetics 52:724-728

Wessells KR, Brown KH (2012) Estimating the global prevalence of zinc deficiency: results based on zinc availability in national food supplies and the prevalence of stunting. PLoS One 7:e50568

WHO (2008) Worldwide prevalence of anaemia 1993-2005: WHO global database. WHO, Geneva

Yadav OP, Rai KN (2013) Genetic improvement of pearl millet in India. Agric Res 2:75-92

Yadav OP, Mitchell SE, Zamora A, Fulton TM, Kresovich S (2007) Development of new simple sequence repeat markers for pearl millet. J Semi-Arid Trop Agric Res 3:34-37

Yadav RS, Hash CT, Bidinger FR, Cavan GP, Howarth CJ (2002) Quantitative trait loci associated with traits determining grain and stover yield in pearl millet under terminal drought-stress conditions. Theor Appl Genet 104:67-83

Yadav RS, Bidinger FR, Hash CT, Yadav YP, Yadav OP, Bhatnagar SK, Howarth CJ (2003) Mapping and characterization of QTL3E interactions for traits determining grain and stover yield in pearl millet. Theor Appl Genet 106:512-520

Yadav RS, Hash CT, Bidinger FR, Devos KM, Howarth CJ (2004) Genomic regions associated with grain yield and aspects of post-flowering drought tolerance in pearl millet across stress environments and tester background. Euphytica 136:265-277

Yadav OP, Mitchell SE, Fulton TM, Kresovich S (2008) Transferring molecular markers from sorghum, rice and other cereals to pearl millet and identifying polymorphic markers. J Semi-Arid Trop Agric Res 6:1-4 
Yadav OP, Rai KN, Bidinger FR, Gupta SK, Rajpurohit BS, Bhatnagar SK (2012) Pearl millet (Pennisetum glaucum) restorer lines for breeding dual-purpose hybrids adapted to arid environments. Indian J Agric Sci 82:922-927

Yadav OP, Rai KN, Yadav HP, Rajpurohit BS, Gupta SK, Rathore A, Karjagi CG (2016) Assessment of diversity in commercial hybrids of pearl millet in India. Indian J Plant Genet Resour 29:130-136

Yadava DK, Choudhury PR, Hossain F, Kumar D (2017) Biofortified varieties: sustainable way to alleviate malnutrition. Indian Council of Agricultural Research, New Delhi 